\title{
ESTUDO DA COMERCIALIZAÇÃO DA PRODUÇÃO FAMILIAR DO P. A. PALMARES NA FEIRA MUNICIPAL DE PARAUAPEBAS
}

\author{
Ana Paula de Oliveira Almeida ${ }^{1}$; Fernando Michelotti ${ }^{2}$ \\ ${ }^{1}$ Discente do curso de Agronomia, Faculdade de Ciências Agrárias de Marabá (FCAM), Universidade Federal do Pará \\ (UFPA), Marabá, Pará. Bolsista PIBIC Interior. E-mail: aninha_mba@ hotmail.com. \\ ${ }^{2}$ Prof., M.Sc., FCAM, UFPA, E-mail: fmichelotti@ufpa.br.
}

\begin{abstract}
RESUMO: A agricultura familiar é aquela em que o responsável pela gestão da produção (família), é também responsável pela mão de obra, e principal consumidor dos produtos. O objetivo principal da produção agrícola nessa modalidade é garantir a reprodução da família. A eficiência do modo de produção da agricultura familiar já foi comprovada por diversos autores, contudo, estudos têm mostrado que o retorno econômico para as famílias tem sido baixo, sendo a comercialização um ponto de estrangulamento. A esses agricultores poucas opções de comercialização são apresentadas. Nesse contexto as feiras livres surgem como alternativa para escoamento da produção agrícola familiar. Este trabalho objetivou estudar a Feira do Produtor Rural de Parauapebas, e sua importância na comercialização e na geração de renda para as famílias assentada no P. A. Palmares II. O trabalho foi desenvolvido no período de março de 2008 a fevereiro de 2009 e buscou base teórica a respeito de comercialização de produtos da agricultura familiar e feiras, em livros e artigos; Contou com visitas à feira; Coleta de dados a respeito de comercialização no arquivo da secretaria da feira; Conversa com os responsáveis pela feira e alguns feirantes das distintas localidades e consumidores e visitas ao Assentamento Palmares II. Verificou-se que a Feira do Produtor Rural em Parauapebas, criada em fevereiro de 1992, pela prefeitura de Parauapebas teve inicio com cerca de 20 produtores cadastrados e hoje possui 480. É mantida pela Prefeitura de Parauapebas através da Secretaria Municipal de Produção Rural que faz a manutenção do local de comercialização; disponibiliza oito caminhões, que percorrem diferentes rotas para conduzir os agricultores à feira; disponibiliza casa de apoio ao agricultor, para alojamento destes. Além de fornecer tratores e assistência técnica. Funciona terça feira, pela tarde, quarta feira pela manha, sexta pela tarde e sábado pela manha. Movimenta em média R $\$ 300.000,00$ por mês, sendo os assentamentos Palmares I e II responsável por cerca de $48 \%$ deste valor. Os produtos comercializados pelos feirantes foram divididos em cinco grupos: frutas, que compreende 23 produtos; olerícolas, listando 20 produtos; grãos, a exemplo do feijão e fava, sendo listados 4 produtos; produtos processados, que compreende produtos que passaram por algum processo de transformação e agregação de valor, a exemplo da farinha, do queijo, e do azeite de babaçu, sendo listado 7 produtos; e um último grupo formado por 5 produtos que não se enquadram nos grupos anteriores, este produtos são vendidos esporadicamente, conforme a necessidade da família, como exemplo palmito e ovos. O grupo com maior participação financeira foi o grupo de produtos processados com 39\% o que corresponde a $\mathrm{R} \$ 34.578,15$ em média por mês; seguido pelas olerícolas com $31 \%$ correspondendo a média mensal de $\mathrm{R} \$ 27.090,67$; e as frutas com $21 \%$, $\mathrm{R} \$$ 18.861,80, em média mensais. Conclui-se que a Feira do Produtor Rural no Município de Parauapebas apresenta-se como alternativa de geração de renda para essas famílias, que por sua vez gera melhorias no sistema produtivo familiar, e, traz benefícios aos consumidores, que encontram produtos de melhor qualidade, com preços mais baixos.
\end{abstract}

PALAVRAS-CHAVE: Agricultura familiar, comercialização, feira de produtor rural. 